\title{
Decommissioning of Offshore Installations: a Fragmented and Ineffective International Regulatory Framework
}

\author{
Seline Trevisanut
}

After decades of exploitation of offshore resources the problem of managing and removing platforms and installations constructed for this purpose urgently presents itself. The number of installations which are reaching the end of their life-cycle are increasing. The issue of removing outdated platforms and installations has become prominent since the 1980s. Due to technological advances in the oil and gas industries, the exploration of resources has extended to new depths and distances, increasing the number of structures in the sea and the impacts on the seabed. For instance, in 1950 there were only two offshore drilling rigs in the world. Yet, by 1988 the number of installations rose to $75^{0},{ }^{1}$ and currently, around 7000 offshore platforms around the world are engaged in the exploitation of hydrocarbons. ${ }^{2}$

* The author would like to thank Nina Mileva for her research, Nikolaos Giannopoulos for his comments on previous drafts of this chapter, and Vivian Aiyedogbon for her editing work. The research for this paper has been conducted thanks to the financial support of the European Research Council under the European Union's Horizon 2020 research and innovation programme (Grant Agreement No 639070 - SUSTAINABLEOCEAN).

1 Z. Gao, 'International Law on Offshore Abandonment: Recent Developments, Current Issues and Future Directives', in Z. Gao (ed.), Environmental Regulation of Oil and Gas, London-The Hague-Boston, 1998, at 144.

2 Möller indicates that ' $\mathrm{t}$ ] here are around 6.500 installations worldwide, about 4.000 of which are in the US Gulf of Mexico, 950 in Asia, 700 in the Middle East and 400 in Europe'; L. Möller, 'UN law on decommissioning offshore installations', M. Hammerson (ed.), Oil and Gas Decommissioning, Global Business Publishing, London, 2013, at 33. Lyons suggests however that there are more than ' 7000 offshore platforms installed globally for hydrocarbon exploration and production'; Y. Lyons, 'The New Offshore Oil and Gas Installations Abandonment Wave and the International Rules on Removal and Dumping', 29 The International Journal of Marine and Coastal Law (2014) 480-520, at 480. 
Abandoned and decommissioned installations pose two main problems: firstly, they can consist of a threat to the safety of navigation, and secondly, they can be harmful to the marine environment. Already in 1958, the Geneva Convention on the Continental Shelf required the complete removal of abandoned and decommissioned installations, ${ }^{3}$ because the exploitation of resources in the continental shelf should not result in any 'unjustifiable interference' with navigation, fishing, or the conservation of the living resources of the sea. ${ }^{4}$ This rule however, was designed to mainly address unjustifiable interferences with other legitimate uses of the sea and the seabed. ${ }^{5}$ The environmental aspect was not the main concern of the drafters in the early developments of the law of the sea, and this approach was subsequently confirmed with the adoption of the 1982 United Nations Convention on the Law of the Sea (UNCLOS). ${ }^{6}$

Nevertheless, installations of the latest generation have been designed and built considering the protection of the environment and the relevant legal framework. First generation structures, built in the period between $195^{\circ}$ and 1960 , were indeed designed without any consideration for the potential need for their removal or abandonment. The issue of dealing with old structures became a point of concern for states only in the late 1980s. Actually, even the agreements on joint management and exploitation of offshore resources concluded in that period do not contain any specific provisions in this regard. The provisions concerning the prevention or reduction of pollution only referred to activities of extraction and transport of oil and gas. ${ }^{7}$

The international community however considered the issue at an earlier stage. The first steps towards managing the problem at the international level can be traced back to the Declaration of the United Nations Conference on

3 Art. 5, par. 5, of the $195^{8}$ Geneva Convention on the Continental Shelf, made in Geneva on 29 April 1958, entered into force on 10 June 1964.

4 Art. 5, par. 1, of the 1958 Geneva Convention on the Continental Shelf.

5 T. Treves, Codification du droit international et pratique des Etats in le droit de la mer, in Recueil des Cours de l'Académie de droit international de la Haye, 1990-IV, at 204.

6 Signed at Montego Bay on 10 December 1982, entered into force on 16 November 1994. Regarding the negotiations preceding the adoption of UNCLOS in 1982, Treves emphasized that 'le respect généralisé dont font l'objet les activités en matière pétrolière de ces temps de crise de l'énergie (années 1970) explique (...) le moins d'attention et de réglementation qu'a reçu jusqu'ici la pollution dérivant de ces activités'; cf. T. Treves, La pollution résultant de l'exploration et de l'exploitation des fonds marins en droit international, in Annuaire Français de Droit International, 1978, at 828.

7 M. Bathurst (ed.), Joint Development of Offshore Oil and Gas, A Model Agreement for States for Joint Development with Explanatory Commentary, London, 1989, at $355 \mathrm{ff}$. 
the Human Environment adopted in 1972 in Stockholm. ${ }^{8}$ Principle 21 of this Declaration contains a reminder that 'States have $[. .$.$] the sovereign right to$ exploit their own resources pursuant to their own environmental policies', specifically pointing out their 'responsibility to ensure that activities within their jurisdiction or control do not cause damage to the environment of other States or of areas beyond the limits of national jurisdiction' [emphasis added]. The reference to offshore activities is quite explicit, and addresses their development in the 1970s. Twenty years later, in 1992, Chapter 17 of the Agenda 21, concerning the 'Protection of the Oceans', details the obligations on states with respect to the prevention and fight against 'the degradation of the marine environment due to offshore activities', and provides in particular:

States, acting individually, bilaterally, regionally or multilaterally and within the framework of IMO (International Marine Organization) and other relevant international organizations, [...] should assess the need for additional measures to address degradation of the marine environment [...] (c) From offshore oil and gas platforms, by assessing existing regulatory measures to address discharges, emissions and safety and assessing the need for additional measures. (para. 17.30).

This text, adopted prior to the entry into force of UNCLOS, highlighted a gap in the regime related to offshore installations and the need for a regulatory effort in this direction. ${ }^{9}$

More than twenty years after the adoption of Agenda 21, it may be noted that some grey areas persist, particularly with respect to the regime concerning abandoned or decommissioned platforms and installations. One can wonder whether there exists a general obligation to remove outdated structures, and if it does, what its content is. Furthermore, it can be discussed whether the removal of abandoned and disused structures and platforms is in the best interest of the marine environment. In fact, several examples in practice show

8 Declaration of the United Nations Conference on the Human Environment, Stockholm, 5-15 June 1972, available at $<$ http://www.unep.org $>$.

9 The accident of the Deepwater Horizon drilling rig owned by the oil company British Petroleum (BP) in the Gulf of Mexico in April 2010 and its aftermath highlighted the gray areas that exist in this area of activity and related regulations. See, among others, R. Abeyratne, 'The Deepwater Horizon Disaster - Some Liability Issues,' in Tulane Maritime Law Journal, 2010, at 125 ff.; C. Chatterjee, Anna Lefcovitch, The Gulf of Mexico Oil Disaster : some Legal Issues, in Amicus curiae: journal of the Society for Advanced Legal Studies, 2010, at $17 \mathrm{ff}$. 
the potential of former industrial structures to become artificial reefs offering habitats to certain species of fish. ${ }^{10}$

The present chapter analyses the international legal framework applicable to the decommissioning of offshore installations and highlights its ambiguities. The chapter also stresses how states still enjoy a broad discretion on how to deal with the issue at hand, specifically on whether to remove (partially or integrally) or not disused installations. This situation coupled with the fragmentation of the international regulatory framework is especially detrimental to the protection of the marine environment.

The analysis unfolds in four steps. First, the legal regime incorporated into the UNCLOS is sketched. The content of the obligation of partial removal is discussed and particular attention is given to the rules of reference contained in the relevant provisions (2). Then, the chapter focuses on the global generally accepted international rules and standards (GAIRs) and the instruments elaborated by the IMO (3). Thereafter, the focus moves to the GAIRs elaborated at the regional level in order to then present (4), in the following section, some considerations on the interaction between the universal GAIRS and regional instruments (5). The concluding remarks then stress how the lack of a binding instrument at the universal level and the geographical fragmentation of the existing legal regime act as an obstacle to the development of clear global GAIRS and ergo to a more coherent (and effective) legal framework for the decommissioning and removal of offshore installations (6).

\section{2 \\ The Law of the Sea Convention Framework}

\subsection{The Obligation of Partial Removal}

With the 'offshore-isation'11 of the exploitation of oil and mineral resources, the UNCLOS entered a new cycle of expansion of the rights of coastal states. ${ }^{12}$ Technological advances and the increasing need for energy have added value to offshore seabed areas rich in natural resources, and over which coastal

10 M.J. Kaiser, Y. Yu, B. Snyder, 'Economic feasibility of using offshore oil and gas structures in the Gulf of Mexico for platform-based aquaculture,' in Marine Policy (2010) $699 \mathrm{ff}$.

11 T. DAHOU, 'La politique des espaces maritimes en Afrique. Louvoyer entre local et global,' in Politique africaine, n. 116, December 2009, at 10.

12 Idem (requests for extension of the continental shelf beyond 200 nautical miles). 
states exercise sovereignty. ${ }^{13}$ Therefore, in its exclusive economic zone (E EZ $)^{14}$ and continental shelf, ${ }^{15}$ a coastal State has the right to build or authorize the construction of artificial islands, installations and structures for the exercise of licensed activities (Article 6o(1); Article 80 UNCLOS$^{16}$ ). These activities fall exclusively in its jurisdiction (Article 6o(2)). The question of management of abandoned and decommissioned structures and platforms is addressed directly in Article 6o para. 3, which provides:

Due notice must be given of the construction of such artificial islands, installations or structures, and permanent means for giving warning of their presence must be maintained. Any installations or structures which are abandoned or disused shall be removed to ensure safety of navigation, taking into account any generally accepted international standards established in this regard by the competent international organization. Such removal shall also have due regard to fishing, the protection of the marine environment and the rights and duties of other States. Appropriate publicity shall be given to the depth, position and dimensions of any installations or structures not entirely removed. [emphasis added]

From a strictly textual reading of the provision, it can be deduced that Article 6o(3) does not impose an absolute obligation to remove offshore installations. While the general rule seems to be that of removal, the second part

13 Article 193 UNCLOS provides: 'States have the sovereign right to exploit their natural resources pursuant to their environmental policies and in accordance with their duty to protect and preserve the marine environment'.

14 The rights and obligations of coastal States in their exclusive economic zone are defined in Article 56 of UnCLOS. The exclusive economic zone is defined in Article 55 as: 'an area beyond and adjacent to the territorial sea, subject to the specific legal regime established in this Part, under which the rights and jurisdiction of the coastal State and the rights and freedoms of other States are governed by the relevant provisions of this Convention'.

15 The rights of the coastal State with respect to its continental shelf are defined in Article 77 of UNCLOS. The continental shelf is defined in Article 76(1) as : 'the seabed and subsoil of the submarine areas that extend beyond its territorial sea throughout the natural prolongation of its land territory to the outer edge of the continental margin, or to a distance of 200 nautical miles from the baselines from which the breadth of the territorial sea is measured where the outer edge of the continental margin does not extend up to that distance'.

16 Article 80 of UnCLOS provides that Article 60 of UNCLOS 'applies, mutatis mutandis, to artificial islands, installations and structures on the continental shelf.' The analysis and considerations regarding Article 60 of UNCLOs which will be detailed later in this study are also valid for structures on the continental shelf. 
of the provision focuses on the safety of navigation, which weakens the absolute nature of the obligation. The removal seems to be mandatory only when the safety of navigation is at stake; thus it could be inferred that if the safety of navigation is not endangered, the structures could be left in place. Other legitimate uses of the sea (fishing) and the protection of the environment should be given 'due regard' in the decision making process, but do not consist of self-standing grounds for justifying the removal of the structure. Moreover, what clearly emerges is that entire installations and structures cannot be abandoned. The last part of Article 6o(3) rather explicitly provides for an obligation to publicize 'the depth, position and dimensions of any installations or structures not entirely removed'. Nonetheless, Article 6o(3) of UnCLOS only contains an obligation of partial removal, in order to ensure the safety of navigation.

This provision has raised much criticism ${ }^{17}$ particularly since the wording of Article 6o(3) differs substantially from that of the precedent Article 5(5) of the 1958 Geneva Convention on the Continental Shelf. The latter called on States to completely remove abandoned and disused installations. ${ }^{18}$ Nevertheless, some authors read Article 6o(3) as imposing a general obligation of full removal in order to ensure the safety of navigation, and saw abandonment or partial removal as exceptions subject to specific justifications. ${ }^{19}$

Articles 60 and 8o UNCLOS only apply to installations in the EEZ and continental shelf. There is no specific provision concerning installations in the territorial sea except that the coastal state can condition the exercise of the right of innocent passage to their protection (Article 19.2(k)); and 'shall give appropriate publicity to any danger to navigation, of which it has knowledge, within its territorial sea, as for instance to offshore installations in activity or disused (Article 24.2). The coastal state is then bound by a series of obligations

17 See, among others, Z. Gao, 'Current Issues of International Law on Offshore Abandonment, with Special Reference to the United Kingdom,' in Ocean Development and International Law, 1997, at 59 ff. ; G.C. Kasoulides, 'Removal of Offshore Platforms and the Development of International Standards,' in Marine Policy, 1989, at 249 ff. ; AT McDade, 'The Removal of Offshore Installations and Conflicting Treaty Obligations as a Result of the Emergence of the New Law of the Sea: A Case Study, in San Diego Law Review, 1987, at 645 ff.; A. Reglat-Boireau, 'La désaffectation des installations en mer', in Annuaire français de droit international, 1982, at $873 \mathrm{ff}$.

18 Article 5(5) of the Convention on the Continental Shelf reads: Due notice must be given of the construction of any such installations, and permanent means for giving warning of their presence must be maintained. Any installations which are abandoned or disused must be entirely removed [emphasis added].

19 R. Wolfrum, N. Matz, Conflicts in International Environmental Law, Berlin-Heidelberg-New York, 2003, pat 110-111. 
for the protection of the marine environment pursuant to Part XII UNCLOS, which also applies to the territorial sea. ${ }^{20}$

While exercising their sovereign rights pursuant to Article 193, a state shall comply with 'the obligation to protect and preserve the marine environment,' set in Article 192; and take the necessary measures to prevent, reduce and control pollution (Article 194). ${ }^{21}$ Coastal states have a duty to ensure that pollution arising from activities within their jurisdiction and control does not extend beyond those areas (Article 194(2)). ${ }^{22}$ If there is an imminent risk of damage to the marine environment, the coastal state has an obligation to notify any other state, which might be affected by such damage (Article 198).

Article 208 UNCLOS regulates the prevention, reduction and control of the pollution from seabed activities subject to national jurisdiction. This is, for instance, the pollution generated by the offshore oil and gas industry located in the EEz or continental shelf. Coastal states are required to adopt laws, regulations and measures that 'shall be no less effective than international rules, standards and recommended practices and procedures' (Article 208(3), emphasis added). ${ }^{23}$ Moreover, states, 'acting especially through competent

20 R. Beckman, 'Global Legal Regime on the Decommissioning of Offshore Installations and Structures', in M. Nordquist et al., The Regulation of Continental Shelf Development, Rethinking International Standards, Martinus Nijhoff, Leiden, 2013, 259-280, at 279.

21 For a recent interpretation of those articles in relation to the construction of installations and artificial islands, see Permanent Court of Arbitration, The South China Sea Arbitration, Award of 12 July 2016, spec. paras $983 \mathrm{ff}$.

This UNCLOS provision re-affirms the well-established customary norm prohibiting transboundary pollution. First affirmed in the Trail Smelter case (United States v. Canada, 11 March 1941, RIAA 1941 vol. III, 1905), the International Court of Justice (ICJ) provided that 'The existence of the general obligation of States to ensure that activities within their jurisdiction and control respect the environment of other States or of areas beyond national control is now part of the corpus of international law relating to the environment' (ICJ, Advisory opinion on the legality of the threat or use of nuclear weapons, 8 July 1996, para. 29). See also Y. Lyons, 'Transboundary Pollution from Offshore Oil and Gas Activities in the Seas of the Southeast Asia', in R. Warner, S. Marsden (eds.), Transboundary Environmental Governance. Inland, Coastland and Marine Perspective (Ashgate, 2012) 167 .

23 UNCLOS does not define concepts such as 'international rules', 'standards' and 'recommended practices and procedures', which remain vague also in practice. See R.R. Churchill and A.V. Lowe, The Law of the Sea, 3rd edition (Manchester University Press, Manchester, 1999) at 346; B. Oxman, 'The duty to Respect Generally Accepted International Standards', New York University Journal of International Law and Politics, 1991-92, vol. 24, pp. 109 ff.; S. Trevisanut, 'La Convention des Nations Unies sur le droit de la mer et le droit de l'environnement : développement intrasystémique et renvoi intersystémique', in H. Ruiz Fabri and L. Gradoni (eds.) La circulation des concepts juridiques: le droit 
international organizations or diplomatic conference, shall establish global and regional rules, standards and recommended practices and procedures to prevent, reduce and control pollution of the marine environment referred to in paragraph 1' (Article 208(5), emphasis added). This provision builds an important 'bridge' between the UNCLOS and other relevant normative sources, which do not necessarily generate from treaties, but derive from the work of relevant actors. Such includes, international organizations; diplomatic conferences; and professional associations which develop recommendations and best practices in a specific economic sector. ${ }^{24}$

A similar rule of reference ${ }^{25}$ is also contained in Article 210 UNCLOs concerning the prevention, reduction and control of pollution by dumping. Dumping consists of the placement for disposal at sea of wastes and other materials, and of 'vessels, aircraft, platforms or other man-made structures at sea' (Article 1(5)). The abandonment of installations or parts of the installations can be considered dumping ${ }^{26}$ and thus falls under the relevant legal regime. The substantive rules on dumping and on seabed activities have been (or should have been developed) outside the UNCLOS, and within the framework that the convention creates through reference to generally accepted rules and standards (GAIRS) and the duty to respect them.

\subsection{The Duty to Respect Generally Accepted Rules and Standards}

UNCLOS was born as a framework convention and a living instrument. In order to avoid becoming outdated (or even obsolete), the drafters resorted in using rules of reference in many of its provisions, ${ }^{27}$ in particular in those creating

international de l'environnement entre mondialisation et fragmentation (Société de législation comparée, 2009) 416. The issue is further discussed below (see Section 2.2.)

24 C. Redgwell, 'Mind the Gap in the GAIRS: The Role of Other Instruments in LOSC Regime Implementation in the Offshore Energy Sector', in N. Bankes, S. Trevisanut (eds), Energy from the Sea: An International Law Perspective on Ocean Energy, Brill Nijhoff, 2015, at 40.

25 Roach highlights how the rules of reference in art. 208 is however slightly different that the one contained in other articles regulating pollution: 'It should be recognized that this firm requirement on States ("shall adopt") contrast sharply with the much looser standard of "shall endeavour" to establish rules in article 207 (pollution of the marine environment from land-based sources), in article 210 (by dumping), and in article 212 (from and through atmosphere);' A. Roach, 'International Standards for Offshore Drilling', in M.H. Nordquist et al. (eds), The Regulation of Continental Shelf Development, Rethinking International Standards (Martinus Nijhoff, Leiden, 2013) 105.

26 For a discussion on whether the abandonment of installation qualifies as dumping, see inter alia Y. Lyons, (n2), 484-491.

27 On the drafting history of the rules of reference see Oxman, (n23), at $121 \mathrm{ff}$. 
obligations in the field of environmental protection. Article 6o(3) provides that the removal of any installations should be performed 'taking into account any generally accepted international standards established in this regard by the competent international organization' (emphasis added). Moreover, Article 208 provides that, states shall not only adopt laws, regulations and measures 'no less effective than international rules, standards and recommended practices and procedures' (para. 3, emphasis added), but they shall also elaborate those 'global and regional rules, standards and recommended practices and procedures to prevent, reduce and control pollution of the marine environment' from seabed activities (para. 5, emphasis added). Additionally Article 210(4), concerning pollution by dumping, encourages states, 'acting especially through competent international organizations or diplomatic conference, (...) to establish global and regional rules, standards and recommended practices and procedures to prevent, reduce and control such pollution.'

The IMO has taken the lead concerning both the treatment of disused installations and pollution by dumping. It has elaborated some guidelines for the removal of installations and is the depositary of the London Dumping Convention, both discussed below. However, its role in the development of the regulatory framework in relation to the offshore oil and gas industry has raised some criticism. ${ }^{28}$ The IMO mandate, as amended, includes 'the general adoption of the highest practicable standards in matters concerning maritime safety (...) and prevention and control of marine pollution from ships.' ${ }^{29}$ Notwithstanding, the IMo Legal Committee has pointed out: 'while pollution directly arising from exploration/exploitation is however not of direct concern of IMO, the Organization may contribute to the establishment of international regulations.' ${ }^{30}$ The Iм0 Legal Committee in particular supports the development of guidance for states in their effort to conclude arrangements at the bilateral and regional level on liability and compensation issues connected to transboundary pollution damage, resulting from offshore oil exploration and

28 Some states and some commentators have raised several points of criticism about the role of the IMO in the development of rules and standards concerning offshore installations. The details of such debate are beyond the scope of the present chapter. For a critical voice, refer to J.A. Roach, 'International Standards for Offshore Drilling,' in M.H. Nordquist et al. (eds) The Regulation of Continental Shelf Development, Rethinking International Standards, Martinus Nijhoff, Leiden, 2013, at 107.

29 Convention on the Intergovernmental Maritime Consultative Organization (Geneva, 6 March 1948, in force 17 March 1958) 289 UnTS 3, emphasis added.

30 See 'Implications of the United Nations Convention on the Law of the Sea for the International Maritime Organization', IMO Doc. LEG/Misc.7 Annex, 19 January 2012, at 18. 
exploitation. ${ }^{31}$ Not all IMO contracting parties, however, have support for what they perceive as an unjustified extension of the IMO mandate. ${ }^{32}$ This undermines the 'generally accepted' character of the rules and standards which the organisation elaborates.

General acceptance needs to be assessed then on the basis of the subsequent practice of states. Consequently, the 1989 Imo Guidelines and Standards for the Removal of Offshore Installations and Structures on the Continental Shelf and in the Exclusive Economic Zone (hereinafter, 1989 IMo Guidelines) ${ }^{33}$ are considered as GAIRs. ${ }^{34}$ Within the London Dumping system, Lyons for instance suggests that, unlike the 1972 London Convention, its 1996 Protocol does not yet qualify as global rule under UNCLOS because it has gained general acceptance only in some regions of the world. ${ }^{35}$ This also suggests that the 1996 Protocol may be regarded as GAIRS in some areas of the world where the majority of relevant states has ratified it, and hence as regional GAIRS and not global rules.

This interpretation can find further support in the joint reading of Articles 208 and 210 with Article 237 UNCLOS. Article 237 consists of a specific compatibility clause for Part XII of the UNCLOS. The provision in particular affirms that the provisions of Part XII are 'without prejudice (...) to agreements which may be concluded in furtherance of the general principles set forth in this Convention' (para. 1). This provision facilitates the application of UNCLOS in the relevant normative context and of environmental law instruments in the context of marine environment protection. It enables the application of the 1996 Protocol, within the UNCLOs, for states that are parties to it, and thus recognises their practice as relevant for the interpretation and application of the relevant UNCLOS provisions (Articles 208 and 210).

31 See IMO doc. LEG 99/14, 24 April 2012, at para. 13.16.

32 A. Roach, 'International Standards for Offshore Drilling', at 105. See also see A. Chircop, 'The International Maritime Organisation,' in D.R. Rothwell et al., The Oxford Handbook of The Law of the Sea, Oxford University Press, Oxford, 2015, at 429.

33 IMO, Resolution A.672 (16), of 19 October 1989.

34 Y. Lyons, 'The New Offshore Oil and Gas Installations Abandonment Wave,' n_, at 495. Contra, see A. Proelss, United Convention on the Law of the Sea, A Commentary, Beck/ Hart, Oxford, 2017, at pp. 474-475.

Ibid., at 506, 510 . 


\section{Generally Accepted International (Global) Rules and Standards}

\subsection{IMO Guidelines}

The obligation of partial removal, as affirmed in the UNCLOS, is justified by financial considerations surrounding the operation, and confirmed by the 1989 IMO Guidelines. ${ }^{36}$ These Guidelines were developed by the IMO pursuant to its competences in the field of maritime safety ${ }^{37}$ and are thus primarily concerned with the safety of navigation. They deal to a lesser degree with fisheries and the environment, as the mandate of the IMo does not include general jurisdiction over environmental matters.

The Guidelines provide that the processing of installations is performed pursuant to a case by case determination by the coastal State. They are therefore characterized by a high degree of flexibility, which contributes to their success with coastal states. ${ }^{38}$ Furthermore, the Guidelines provide for the removal of installations which are located at a depth of less than 75 meters, and weigh less than 4000 tons. Nonetheless, the possibility of partial removal or abandonment of the structures remains in cases when their removal is not feasible from a technical point of view (first generation structures); when the removal is excessively costly; or when the removal might pose an unacceptable risk for people or for the environment. Additionally, the Guidelines accommodate the possibility of re-using installation, in particular as an artificial reef for the development of fisheries. This is in line with the general criteria for removal provided by Article 6o(3), namely that the removal procedure has due regard,

36 Imo, Resolution A.672 (16), of 19 October 1989, paras 3.6, 3.8, 3.12. In this regard see R. Beckman, 'Global Legal Regime on the Decommissioning of Offshore Installations and Structures', in M. Nordquist et al., The Regulation of Continental Shelf Development, Rethinking International Standards, Martinus Nijhoff, Leiden, 2013, at 266.

37 S. Rosenne, 'The International Maritime Organization Interface with the Law of the Sea Convention,' in M.H. Nordquist, J.N. Moore (eds.), Current Maritime Issues and the International Maritime Organization, The Hague-Boston-London, 1999, at 26o. The author recalls that UNCLOS requires the collaboration of the IMO, as the competent international organization in 72 sectors, 19 of which are not shared with other organization (such as FAO, ILO, or ICAO). The development of standards for the removal of offshore stuctures is featured among the 19 sectors over which the Imo has jurisdiction. On the role of the IMO in the development of international rules and standards, see A. Chircop, (n32), at 429; S.N. Nandan, S. Rosenne (eds.), United Nations Convention on the Law of the Sea 1982, A Commentary, vol. II, Dordrecht-Boston-London, 1993, at 587; T. Treves, (n5) at 206.

38 T. Treves, (n5), at 205: 'The success of the Imo initiative seems to confirm that the requirement to introduce a measure of flexibility in the rule on the obligation to remove is widespread in the international community'. 
not only to the security of navigation, but also to 'fishing, the protection of the marine environment and the rights and duties of other States' ${ }^{39}$

As illustrated by the 1989 IMO Guidelines, the objective of environmental protection sometimes clashes with the obligation to remove an installation when the latter has become an artificial habitat for natural resources, mainly for some fish stocks. ${ }^{40}$ An abandoned or decommissioned offshore installation which has become an artificial habitat for certain species may still however be considered a form of pollution when it is an obstacle to fishing and other legitimate uses of the sea. States consequently find themselves balancing between environmental interests, especially the obligation to protect living resources, on the one hand, and the prevention and control of pollution on the other hand. More specifically, states find themselves stranded between, first, Articles 208 and 214 concerning the pollution resulting from seabed activities, and second Articles 56, 61, 117 and 118 concerning the protection of living resources. The Guidelines do not provide any further guidance on how to strike such a balance, leaving an important margin of discretion to coastal states.

\subsection{London Dumping Convention and Its 1996 Protocol}

As mentioned above, the remains of or disused structures can also be abandoned in accordance with the 1972 London Convention for the Prevention of Marine Pollution by Dumping of Wastes and Other Matter (hereinafter, 1972 London Convention).$^{41}$ Article III of the 1972 London Convention (replaced

39 Some authors claim that paragraph 3 of Article 60 does not impose any absolute obligation as to the removal of facilities but rather suggests general criteria for determining the removal procedures in specific cases; see S.N. Nandan, S. Rosenne (eds.), (n37) at 585 .

There are even mentions of a "beneficial" environmental effect of certain structures which develop into habitats for commercially relevant species; see K. Bangert, 'Environment Protection - Offshore, Oil and Gas Production', in U. Karpen (ed.), Maritime Safety Current Problems of Use of the Baltic Sea, Baden-Baden, 2005, 88; P Macreadie. A. Fowler, B. Booth, 'Rigs to Reef: will the Deep Sea Benefit from Artificial Habitats?', in Frontiers in Ecology and the Environment (2011) 455. According to Beckman, '[t]here are three methods by which installations and structures could be used for the creation of artificial reefs. First, the top part could be removed and the bottom of the structure left in-situ, with sufficient clearance so that it does not pose a threat to navigation. Second, the structure could be toppled on site with sufficient clearance so that it does not pose a threat to navigation. Third, the structure could be cut up and parts of it moved to specific locations to attract marine life'; R. Beckman, 'Global Legal Regime on the Decommissioning of Offshore Installations and Structures', in M. Nordquist et al., The Regulation of Continental Shelf Development, Rethinking International Standards, Martinus Nijhoff, Leiden, 2013, at 275 .

41 Signed in London on 29 December 1972, entered into force on 30 August 1975. The 1972 Convention was substituted by the 1996 Protocol. 1996 Protocol to the Convention on the Prevention of Marine Pollution by Dumping of Wastes and Other Matter, signed in London on 7 November 1996, entered into force on 24 March 2006. 
by the 1996 Protocol) provides that 'dumping' means 'any deliberate disposal at sea of vessels, aircraft, platforms or other manmade structures at sea'. The 1972 London Convention does not contain a comprehensive ban on dumping, ${ }^{42}$ and neither does the 1996 revised text of the Convention provide for an absolute prohibition of dumping of platforms and installations.

Through its amending Protocol of 1996, the 1972 London Convention integrates the precautionary principle. This reverses the logic of the previous system by prohibiting the dumping of seriously harmful substances ${ }^{43}$ and the incineration of waste at sea. The preamble of the Protocol also considers relevant international instruments, including in particular UNCLOS, the Rio Declaration and Agenda 21 of 1992. Article 210 (5) and (6) of UNCLOS concerning pollution through dumping provides:

(5) Dumping within the territorial sea and the exclusive economic zone or onto the continental shelf shall not be carried out without the express prior approval of the coastal State, which has the right to permit, regulate and control such dumping after due consideration of the matter with other States which by reason of their geographical situation may be adversely affected thereby. (6) National laws, regulations and measures shall be no less effective in preventing, reducing and controlling pollution than the global rules and standards. [emphasis added]

The UNCLOS here refers to the 1972 London Convention, ${ }^{44}$ which preceded the UNCLOS and was taken into account in the drafting process. UNCLOS suggests the possibility of normative developments leading to a stricter regime. Indeed,

42 Z. Gao, (n1) at 164.

43 Pursuant to Article IV of the 1972 Convention, before its amendment in 1996, substances whose dumping is completely prohibited are inserted into the 'black list' of Annex I to the Convention; then there is the 'gray list' of Annex II, which contains the names of substances whose dumping requires special permission; and finally Annex III lists the substances and wastes the dumping of which may be allowed in general. Art. 4 of 1996 on the other hand prohibits all dumping except for substances listed in Annex 1, the dumping of which is subject to obtaining an authorization under the criteria set out in Annex 2. C. Redgwell, 'From Permission to Prohibition: The 1982 Convention on the Law of the Sea and the Protection of the Marine Environment', in D. Freestone, R. Barnes, D.M. Ong (eds.), The Law of the Sea, Progress and Prospects, Oxford, 2006, at 190 : 'Far from being self-contained regimes, the [UNCLOS] and the London Convention of 1972 can be defined as 'Reinforcing integrated schemes', insofar as they contaminate each other by absorbing the changes that occur on one side and another, but also outside, as in the grounds of the IMO'; see also S. Trevisanut, 'La Convention des Nations Unies sur le droit de la mer et le droit de l'environnement: développement intrasystémique et renvoi intersystémique', in H. Ruiz Fabri, L. Gradoni (eds.), La circulation des concepts juridiques : le droit international de l'environment entre mondialisation et fragmentation, Paris 2009, at 411. 
the regime created by the 1972 London Convention, as modified by the 1996 Protocol, may be seen as being slightly stricter than the one created by the UNCLOS. The dumping of offshore platforms and installations is mentioned in Annex 1 of the 1996 Protocol, in reference to wastes or other matter that may be considered for dumping (para. 1.4, Annex 1). The text of the new agreement allows states to adopt stricter national measures banning the dumping of wastes and other materials specified in Annex 1 of the Protocol (Article 4(2) of the 1996 Protocol).

Wastes and other materials may be considered for dumping provided such material that creates floating debris or otherwise contributes to the pollution of the marine environment has been removed; and only when it has been ascertained that the material dumped poses no serious obstacle to fishing or navigation (para. 2, Annex 1). Article 4(1)(2) of the 1996 Protocol indicates that particular attention shall be paid to opportunities to avoid dumping in favour of environmentally preferable alternatives. The national authority responsible for granting permission for dumping must assess the existence of less environmentally harmful alternatives; and the owner of the structure seeking permission to perform dumping must prove that there is no other more preferable alternative. ${ }^{45}$ The regime created by the 1972 London Convention as amended by the 1996 Protocol is slightly stricter than the one created by the UNCLOS, in the sense that full removal is general standard, and dumping is a possible alternative only if there is no evidence to the contrary.

The London Convention system thus creates a presumption in favour of the removal of an abandoned or decommissioned structure. Hypothetically, this preference may be reversed if the structure becomes an artificial reef, namely when the abandonment takes place for environmental reasons, thus for a purpose other than the mere disposal of the installation. Unlike the UNCLOS, the London Convention does not only address coastal States, but also owners of structures who bear the burden of proof with respect to the inevitability of the dumping. These owners (private persons) thus assume an important role in the decision-making process concerning the treatment of disused structures. This might pose a problem with respect to the availability of means, as the two concerned entities - the national authority responsible for the granting of authorizations and the owner of the structure - may not have the same

45 IMO 2000 Specific Guidelines for Assessment of Platforms or Other Man-Made Structures at Sea, para. 5, available at: <https://cil.nus.edu.sg/2000-specific-guidelines-for-assessment -of-platforms-or-other-man-made-structures-at-sea/>. See also H. Esmaeili, The Legal Regime of Offshore Oil Rigs in International Law, Ashgate, Dartmouth, 2001, at 201. 
technical and economic means at their disposal. It is sufficient to think of examples of developing countries where the major oil companies are most active. This imbalance might be mitigated in the future by the work the London Convention/Protocol TC Trust Fund ${ }^{46}$ within the Technical Co-operation Committee (TC) of the Imo. London Convention/Protocol TC Trust Fund is responsible for managing donations for cooperation and technical assistance. The work of the fund is particularly important in regions where no specific instrument regulates the protection of the marine environment, generally, and dumping, specifically. Practices and Procedures

Both Article 208.5 and 210(4) UNCLOS refer to the need to elaborate instruments at the regional level in order to regulate, respectively, pollution from seabed activities and dumping. Four regional seas instruments have either specific provisions or specific instruments regulating the decommissioning of offshore installations and/or their dumping. The content of each regional system is briefly described and analysed in order of strength of their provisions concerning the dumping of installations.

\section{1}

The Offshore Protocol to the Kuwait concerning Marine Pollution Resulting from Exploration and Exploitation of the Continental Shelf The 1989 Offshore Protocol to the Kuwait Regional Convention for Co-operation on the Protection of the Marine Environment from Pollution ${ }^{47}$ permits partial removal in the interests of safety of navigation and fishing (Article XIII(1)(b)). Contracting states shall also have regard to any guidelines issued by the regional organization. The Marine Emergency Mutual Aid Centre (MEMAC) ${ }^{48}$ has however not yet elaborated such guidelines concerning the decommissioning of installations. It has nonetheless adopted Guidelines on Requirements for the

\footnotetext{
46 IMO, doc. LC-LP.1/Circ.33, 19 January 2010.

47 Protocol Concerning Marine Pollution Resulting from Exploration and Exploitation of the Continental Shelf, 2065 UNTs 68, available at <https://treaties.un.org/doc/Publication/ UNTS/Volume\%202065/v2065.pdf>.

48 The Marine Emergency Mutual Aid Centre (MEMAC) was created in 1982 by the Protocol concerning Regional Co-operation in Combating Pollution by Oil and other Harmful Substances in Case of Emergency to the Kuwait Convention. For more information about this regional organisation, see: $<$ http://memac-rsa.org/en/home $>$.
} 
Conduct of Environmental Impact Survey and the Production of Environmental Impact System (hereinafter, Guidelines on Requirements for the Conduct of Environmental Impact Survey). ${ }^{49}$ Those guidelines are particularly important because the Protocol does not contain a clear and general obligation of environmental impact assessment, (EIA) as it allows contracting parties not to require such an assessment before a new activity starts. When the contracting state decides not to request an EIA, it 'shall consider' performing a survey of the marine environment (Article IV.2). Contracting parties then have a wide margin of discretion under this instrument, which is, however, limited by the global legal framework analysed above.

The Guidelines on Requirements for the Conduct of Environmental Impact Survey mention in the terms of reference of the assessment that those terms require the consideration of '[p]lans for removal of any plant or equipment, and any reclamation, restoration or clearing of the site after cessation of operations' $(4.2(\mathrm{j}))$. The same guideline however recognises the wide margin of appreciation to the authority requiring the assessment as it can strike out any term of reference which is considered unnecessary by the objectives of the survey (4.2.). In respect of decommissioning of offshore installations, the Kuwait Convention thus does not provide for clear obligations to complement the general legal framework sketched above.

\subsection{The Dumping and Offshore Protocols to the Barcelona Convention for the Protection of the Mediterranean Sea against Pollution}

The 1976 Barcelona Convention for the Protection of the Marine Environment and the Coastal Region of the Mediterranean contains two instruments which are relevant for the issue at hand: the Protocol for the Prevention of Pollution in the Mediterranean Sea by Dumping from Ships and Aircraft (hereinafter, Barcelona Dumping Protocol, not yet into force $)^{50}$ and the Protocol for the Protection of the Mediterranean Sea against Pollution Resulting from Exploration and Exploitation of the Continental Shelf and the Seabed and its Subsoil (hereinafter, Barcelona Offshore Protocol).51

The Barcelona Dumping Protocol applies to platforms and other structures (Article 3.1) and follows the same rational as the London Convention system,

49 Available here: $<$ http://memac-rsa.org/assets/fileManager/1_GUIDELINES_Impact_Asses sment_1.pdf>.

5o UNEP(OCA)/MED IG.6/7; text available at < http://web.unep.org/unepmap/who-we -are/legal-framework>.

51 UNEP(OCA)/MED IG.4/4; text available at <https://wedocs.unep.org/rest/bitstreams/ $2336 /$ retrieve $>$. 
namely dumping is prohibited except when it is permitted. The Barcelona Offshore Protocol, on the other hand, consists of a quite detailed instrument which aims at covering the complete life-cycle of an offshore operation. In setting a number of mandatory requirements for the authorization procedure (Articles 4-7), the protocol focuses on the role of both authorizing states and the industry, i.e. the operator, in assessing the environmental impact of a planned activity, in monitoring it and in reacting to possible emergencies. ${ }^{52}$ Article 5 in particular requires that the project submitted by the candidate operator also includes ' $(\mathrm{g}$ ) The plans for removal of installations as specified in Article 20.' Article 20 extensively reaffirms Article 60.3 UNCLOS and adds elements concerning the role of private actors. The article provides that:

The operator shall be required by the competent authority to remove any installation which is abandoned or disused, in order to ensure safety of navigation, taking into account the guidelines and standards adopted by the competent international organization. Such removal shall also have due regard to other legitimate uses of the sea, in particular fishing, the protection of the marine environment and the rights and duties of other Contracting Parties. Prior to such removal, the operator under its responsibility shall take all necessary measures to prevent spillage or leakage from the site of the activities (Article 2o(1), emphasis added).

Moreover, Article 20 also creates an obligation upon coastal state to act in the event in which the operator 'fails to comply with the provisions of this Article.' '[T]he competent authority shall undertake, at the operator's expense' any necessary action, including the actual removal of the installation.

The Mediterranean Action Plan, ${ }^{53}$ adopted in the framework of the Offshore Protocol, aims in particular at encouraging the adoption of further safety measures at the regional level, in the time frame of 2016-2024. These measures should include: " $[\mathrm{s}]$ etting-up a governance framework to support the implementation of the Action Plan and the adoption, enforcement and monitoring of regional standards, procedures and rules;' [d]efining commonly agreed regional offshore standards and guidelines'; and develop and adopt '[c]ommon

52 S. Trevisanut, 'The Role of Private Actors in the Offshore Energy Industry,' 29 International Journal of Marine and Coastal Law (2014) 645.

53 Mediterranean Offshore Action Plan in the framework of the Protocol for the Protection of the Mediterranean Sea against Pollution resulting from Exploration and Exploitation of the Continental Shelf and the Seabed and its Subsoil, UNEP(DEPI)/MED IG.22/28, available at: $<$ https://wedocs.unep.org/rest/bitstreams $/ 8_{3} 81 /$ retrieve $>$. 
criteria, rules and procedures for the removal of installations and the related financial aspects adopted. ${ }^{54}$ The Action Plan also provides the creation of two sub-groups within the Barcelona Convention Offshore Oil and Gas Group (BARCO OFOG) which will be in charge of the removal of installation, namely the OFOG Sub-Group on environmental impact and the ofog Sub-Group on health and safety. ${ }^{55}$

In relation to the development of regional standards and guidelines, the document emphasizes the need of Regional Guidelines on removal of installations and the related financial aspects, ${ }^{56}$ highlighting in this way the shortcomings of the global and regional existing legal framework and the crucial importance of clarification and harmonization.

\subsection{The Helsinki Convention on the Protection of the Marine Environment of the Baltic Sea Area}

The Helsinki Convention for the protection of the Marine Environment of the Baltic Sea Area ${ }^{57}$ contains Annex VI on the prevention of pollution from offshore activities. Pursuant to Regulation 8 of Annex VI, concerning disused offshore units, the 'Contracting Parties shall ensure that abandoned, disused, and accidentally wrecked offshore units are entirely removed and brought ashore under the responsibility of the owner' (emphasis added). This regulation restates Article 5(5) of the 1958 Geneva Convention ${ }^{58}$ in stricter terms, and lays the primary responsibility of removal on the private operator (the owner). Differently to the Barcelona Offshore Protocol, the Helsinki Convention does not specify what actions the State should take if the owner of the structure refuses to comply with his responsibilities.

Annex VI applies to all offshore units defined in Regulation 1 which includes: 'any fixed or floating offshore installation or structure engaged in gas or oil exploration, exploitation or production activities, or loading or unloading of oil'. This definition thus limits the scope of application to structures engaged in activities related to the exploration and exploitation of hydrocarbons. Hence, the structures engaged in the production of renewable energy are not included.

54 Ibid, at 214, 220.

55 Ibid, at $215^{-216 .}$

56 Ibid, at 220.

57 Adopted in Helsinki on 24 September 1992, entered into force on 17 January 2000. The text replaces the previous 1992 Convention for the Protection of the Marine Environment of the Baltic Sea for 1974. The agreed text of 1992 was amended four times $(2000,2002$, 2004, 2007). The articles which are referred to in this study correspond to the text as amended by the entry into force in 2008 of the last amendments, available at $<\mathrm{http}$ :// www.helcom.fi>.

$58 \quad$ K. Bangert, $(\mathrm{n} 40)$ at 88. 
The Helsinki Convention then prohibits pollution by dumping. This includes 'any deliberate disposal at sea or into the seabed of wastes or other matter from ships, other man-made structures at sea or aircraft' (Article 2(4) (a)(ii)). Offshore installations, including those which are not engaged in oil and gas sector, should not be dumped; thus, we can assume that there exists a presumption in favour of the removal of such installations. The prohibition of dumping is however not absolute. Contracting parties can issue a permit for the dumping of certain dredged material, provided that the criteria set out in Annex V are respected (Article 11(2)). Moreover, Article 11(3) provides that:

The provisions of this Article shall not apply (...) in any case which constitutes a danger to human life, if dumping appears to be the only way of averting the threat and if there is every probability that the damage consequent upon such dumping will be less than would otherwise occur. Such dumping shall be so conducted as to minimize the likelihood of damage to human or marine life. [emphasis added]

It may be observed that this provision contains the same criteria as the 1996 London Dumping Protocol. Namely, dumping should take place only when no other alternative solution provides comparable guarantees. However, the Helsinki Convention does not provide detailed guidelines on the burden of proof regarding the inevitability of dumping as the London Convention. Given the role assigned to the owner of the offshore installation by Annex VI it may, however, be assumed that the owner is also called to play a role in the determination of the burden of proof for dumping, at least with respect to facilities used by the oil and gas industries.

\subsection{The OSPAR Convention for the Protection of the Marine Environment of the North-East Atlantic}

The North-East Atlantic is filled with offshore structures involved in the exploration and exploitation of non-living resources. Already in the 1970s, coastal states $^{59}$ established a system for the protection of the environment by adopting the 1972 Oslo Convention for the Prevention of Marine Pollution by Dumping.

59 The ospar system has 14 States Parties and the European Commission, representing the European Community, now the European Union. The States Parties are: Belgium, Denmark, Finland, France, Germany, Iceland, Ireland, Luxembourg, the Netherlands, Norway, Portugal, Spain, Sweden, Switzerland, and the UK. Not all Contracting Parties are coastal states. An example of this is Finland, whose participation is justified by the fact that part of its rivers flow into the Barents Sea; Luxembourg and Switzerland are contracting parties as they are located in the Rhine catchment area. For further information see <http://www.ospar.org>. 
In 1974, the Oslo Convention was joined with the Paris Convention for the Prevention of Marine Pollution from Land-Based Sources, thus becoming the ospar Convention for the Protection of the Marine Environment of the North-East Atlantic in $1992 .{ }^{60}$

Annex III of the OSPAR Convention concerning the prevention and elimination of pollution arising from offshore activities contains an absolute prohibition on dumping of wastes and other material (Article 3(1) Annex III) derived from offshore installations. The definition of dumping includes 'any deliberate disposal in the maritime area of wastes or other matter from offshore installations' (Article 1(f)(i)(2) OSPAR Convention) but excludes the full or partial maintenance of the facilities in place, provided that this is compatible with the Convention (Article 1(g)(iii) OSPAR Convent). Article 5(1) of Annex III then specifies that no disused offshore installation shall be left wholly or partly in place in the maritime area without a permit issued by the competent authority on a case-by-case basis. If the disused offshore installation contains substances which may result in hazards for 'human health, harm to living resources and marine ecosystems, (...) or interference with other legitimate uses of the sea', no such permit should be issued (Article 5(2) Annex III). Any such permit should contain the relevant justifications and, since 1st January 1998, need to be communicated to the other OSPAR Contracting Parties through the OSPAR Commission, in order to make consultation possible (Article 5(3) Annex III).

This kind of obligation already existed in the Oslo conventional system. Such is why in February of 1995 the UK Department of Trade and Industry informed the Oslo Commission (the predecessor of the OSPAR Commission) of its intention to grant permission to Shell UK, to dump the remains of the Brent Spar Shell platform which was decommissioned in 1991. In April of the same year, multiple protests against the project were organized by environmental groups, and particularly by the non-governmental organisation Greenpeace. Without going into too much detail concerning the events, ${ }^{61}$ these protests led to a debate during the Meeting of Ministers of the Oslo commission in

6o Concluded in Paris on 22 September, 1992, and entered into force on 25 March, 1998.

61 Many authors have dealt with this subject. See for example: L. de La Fayette, 'New Developments in the Disposal of Offshore Installations,' in InternationalJournal of Marine and Coastal Law, 1999, at 523 ff. ; Z. Gao, (n1), at 59 ff. ; E.A. Kirk, 'The 1996 Protocol to the London Dumping Convention and the Brent Spar', in International and Comparative Law Quarterly, 1997, at 957 ff.; S. Mankabady, 'Decommissioning of Offshore Installations,' in Journal of Maritime Law and Commerce, 1997, at 603 ff. ; J. Woodliffe, 'Decommissioning of Offshore Oil and Gas Installations in Europe Waters: The End of a Decade of Indecision?', in International Journal of Marine and Coastal Law (1999) at $101 \mathrm{ff}$. 
June 1995, which adopted a moratorium on the dumping of offshore installations. In January of 1998, Shell UK announced a new project for the disposal on-shore of the structure.

The immediate consequence of this episode was the adoption of the Decision OSPAR 98/3 for the Disposal of Disused Offshore Installation by the OSPAR Commission in July of $1998 .{ }^{62}$ Pursuant to this text, which entered into force in February of 1999, " $[\mathrm{t}] \mathrm{he}$ dumping, and the leaving wholly or partly in place, of disused offshore installations within the maritime area is prohibited. However, the text states that where 'there are significant reasons why an alternative disposal mentioned below is preferable to reuse or recycling or final disposal on land' the competent authority may issue a permit for exemption to the prohibition. Thus, it may authorise the dumping or abandonment of parts of or the entire structure.

The OSPAR Commission has had a central role in the development of a procedure for the decommissioning and removal of offshore installations. Decision $98 / 3$ with its ban on dumping establishes a presumption in favour of an obligation to remove a disused structure. Moreover, the mandatory system of consultation in case of derogation, provided in Annex 3 of Decision $98 / 3$, guarantees the existence of control, international monitoring, and thus better protection of common interests, such as the protection of the marine environment.

Interaction between Regional and Global Rules: Complementarity and Fragmentation

The regulation of offshore oil and gas operations has developed following a liberal model of regionalism. ${ }^{63}$ There is no attempt in the UNCLOs 'either to impose a uniform global standard comparable to that for ships, or even a minimum standard comparable to that for dumping at sea. ${ }^{64}$ The UNCLOS has thus only partially contributed to the coherent development of the legal framework in this field, mainly through the general obligations for the protection of the marine environment and for partial removal.

\footnotetext{
62 Available at < https://www.ospar.org/work-areas/oic/installations $>$.

63 A. Boyle, 'Globalism and Regionalism in the Protection of the Marine Environment,' in D. Vidas, Protecting the Polar Marine Environment, Law and Policy for Pollution Prevention, Cambridge University Press, Cambridge, 200o, at 24.

64 Ibid.
} 
The existence of specialized regional instruments is a welcome phenomenon which, on the one hand, implements the obligation set in Article 208 UNCLOS and, on the other hand, develops state practice in this field. However, as highlighted in the analysis on the existing instruments, regional approaches seem to diverge on certain key issues, such as, absolute or relative prohibition of dumping and criteria for issuing dumping permits. Moreover, the level of regional integration varies significantly from one regional sea to the other. The OSPAR and Helsinki systems rely on a developed institutional framework which includes supervisory and monitoring bodies, the OSPAR Commission and the Helsinki Commission, respectively. Under the Barcelona Convention, compliance control lies with the Meeting of the Parties and is conducted through the revision of periodical reports submitted by the contracting parties (Articles 18.2 and 27 of the Barcelona Convention; Article 30 of the Barcelona Offshore Protocol). A similar system exists under the Kuwait Convention where the Council of the Regional Organisation for the Protection of the Marine Environment receives and evaluates the reports sent by the contracting parties (Article XVII). These institutional differences impact the level of implementation of the existing obligations and the progressive development of rules and standards at the regional level.

Boyle insightfully remarks that: " $[\mathrm{R}]$ egional cooperation may fragment the possibilities for, and the effectiveness of international supervision of compliance with environmental standards. (...) Without an overarching global scheme comparable to the London [Dumping] Convention, there is (...) no alternative supervisory mechanism and no accountability.65 This is not a call against regionalism. It is more a reminder that regionalism by itself, and in particular weak regionalism, without an international/global framework, does not solve all problems. The global framework is not enough developed at the normative and institutional level in order to guarantee the effectiveness of regional cooperation systems or to offer safeguards against their failures.

Partial or complete removal of offshore installations from the seabed is the generally accepted rule under both global and regional instruments. The conditions under which the removal is supposed to be performed and the criteria for the exceptions however highly diverge from one treaty system to another.

65 Ibid., at 33 . 
This remains highly problematic in light of the considerable number of installations reaching the end of their life-cycle, and of the potential environmental harm they represent.

The lack of an agreed institutional framework should not necessarily consist of an obstacle to the development of a more coherent and comprehensive legal framework. As pointed out by Beckman, " $[\mathrm{i}] \mathrm{f}$ the IMO is not considered to be the competent international organization for this purpose, then interested States should draft a global convention and convene a global diplomatic conference to consider its adoption.' ${ }^{66}$ A specialized framework treaty could be an important step for the offshore industry in general and for the treatment of decommissioned or disused installations in particular. However, Scovazzi aptly highlights that, 'there is little appetite for a global regime, ${ }^{\prime 67}$ notwithstanding, the strict regional model ${ }^{68}$ has poignantly shown its limits.

66 R. Beckman, 'Global Legal Regime on the Decommissioning of Offshore Installations and Structures', in M. Nordquist et al., The Regulation of Continental Shelf Development, Rethinking International Standards, Martinus Nijhoff, Leiden, 2013, at 280.

67 T. Scovazzi, 'Maritime Accidents with Particular Emphasis on Liability and Compensation for Damage from the Exploitation of Mineral Resources of the Seabed, in A. De Guttry et al (eds), International Disaster Response Law, T.M.C. Asser Press, The Hague, 2012, at 457 .

68 Tanaka distinguished four models on interaction between global and regional legal frameworks. Under the first model, the regional model, 'the role of the global treaty is very limited and marine pollution it to be regulated promarily by regional treaties.' The other three models are: the global-single regional model; the global-multiple regional model; and the global model. See Y. Tanaka, 'Four Models on Interaction between Global and Regional Legal Frameworks on Environmental Protection against Marine Pollution: The Case of the Marine Arctic,' Ocean Yearbook (2016) at 346. 